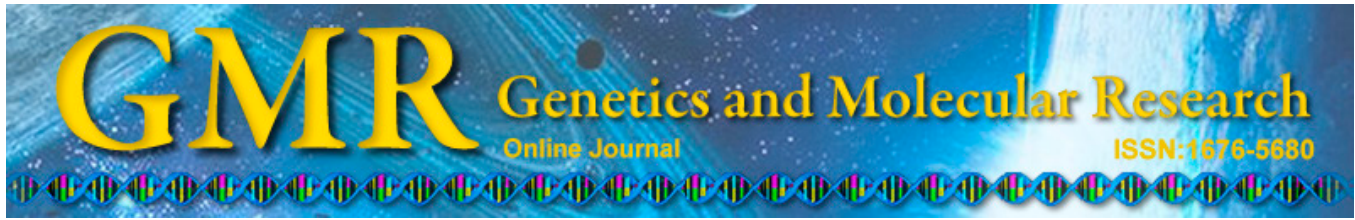

\title{
Increasing genetic variability in black oats using gamma irradiation
}

\author{
G. Silveira ${ }^{1}$, E. Moliterno ${ }^{2}$, G. Ribeiro ${ }^{3}$, P.M.A. Costa ${ }^{1}$, L.G. Woyann ${ }^{4}$, \\ E.W. Tessmann ${ }^{4}$, A.C. Oliveira ${ }^{4}$ and C.D. Cruz ${ }^{1}$ \\ ${ }^{1}$ Programa de Pós-Graduação em Genética e Melhoramento, \\ Universidade Federal de Viçosa, Viçosa, MG, Brasil \\ ${ }^{2}$ Fundação Centro de Experimentação e Pesquisa Fecotrigo, \\ Cruz Alta, RS, Brasil \\ ${ }^{3}$ Departamento de Fitotecnia, Universidade Federal do Pampa, \\ Itaqui, RS, Brasil \\ ${ }^{4}$ Departamento de Fitotecnia, Universidade Federal de Pelotas, \\ Pelotas, RS, Brasil \\ Corresponding author: G. Silveira \\ E-mail: gustavodasilveira.faem@gmail.com
}

Genet. Mol. Res. 13 (4): 10332-10340 (2014)

Received March 12, 2014

Accepted July 22, 2014

Published December 4, 2014

DOI http://dx.doi.org/10.4238/2014.December.4.28

\begin{abstract}
The black oat (Avena strigosa Schreb) is commonly used for forage, soil cover, and green manure. Despite its importance, little improvement has been made to this species, leading to high levels of genotypic disuniformity within commercial cultivars. The objective of this study was to evaluate the efficiency of different doses of gamma rays $\left[{ }^{60} \mathrm{Co}\right]$ applied to black oat seeds on the increase of genetic variability of agronomic traits. We applied doses of $0,10,50$, 100, and 200 Gy to the genotype ALPHA 94087 through exposure to $\left[{ }^{60} \mathrm{Co}\right]$. Two experiments were conducted in the winter of 2008 . The first aimed to test forage trait measurements such as plant height, dry matter yield, number of surviving tillers, and seedling stand. The second test assessed seed traits, such as yield and dormancy levels. Gamma irradiation seems not to increase seed yield in black oats, but it was
\end{abstract}


effective in generating variability for the other traits. Tiller number and plant height are important selection traits to increase dry matter yield. Selection in advanced generations of mutant populations can increase the probability of identifying superior genotypes.

Key words: Avena strigosa Schreb.; Mutagen; Mutant populations; Biomass production; Dormancy

\section{INTRODUCTION}

The cultivation of black oats (Avena strigosa Schreb.) in Brazil has increased because of their yield potential, forage quality, and combined use in direct seeding systems. The area covered by this crop has reached the states of São Paulo, Mato Grosso, Paraná, Santa Catarina, and Rio Grande do Sul. In the State of Rio Grande do Sul, more than 3 million hectares are cultivated annually (Federizzi and Mundstock, 2004). The importance of this species is that this area is 3 times the area of rice, which is one of the major cereals produced in this state (CONAB, 2013).

The availability of black oat cultivars in the market is very restricted. The major cultivated genotype, Preta Comum, is not fixed and may be considered as a mixture of inbred lines. This means that every seed bag has a pool of seeds of unknown origin composed of a wide range of genotypes that can be variable according to the source. Because these seeds are not from a certified origin, they can present variations in the field when different years and locations are compared, even for basic phenotypic traits such as plant stature, disease susceptibility, dry mass yield, and seed dormancy.

The genetic gain obtained in black oats to date occurred, mostly, from selections within the wide pool composing the cultivar Preta Comum, which is successful only for a few characteristics. According to Ertekin (2012), the genetic gain is directly related to the genetic diversity of the target population. Thus, plant variability is key to obtain a continuous gain in the development of superior genotypes. Therefore, the use of techniques that increase the genetic variability in this crop is capital for the generation of alleles coding for desirable phenotypes.

The use of chemical and physical mutagens to increase genetic variability has been reported for many crops (Jain, 2010) and can be incorporated as an additional tool for plant breeding programs. The use of mutations can increase variation in the breeding population compared to the natural population (Ahloowalia and Maluszynski, 2001). In this sense, the objective of this study was to evaluate the efficiency of different doses of gamma rays $\left[{ }^{60} \mathrm{Co}\right]$ applied to black oat seeds on the increase of genetic variability of agronomic traits.

\section{MATERIAL AND METHODS}

\section{Plant material}

Two experiments were conducted in the winter season of 2008 at Capão do Leão, State of Rio Grande do Sul, Brazil (latitude 31 ${ }^{\circ} 52^{\prime} 00^{\prime \prime} \mathrm{S}$, longitude $52^{\circ} 21^{\prime} 24^{\prime \prime} \mathrm{W}$, altitude $13 \mathrm{~m}$ ). The first experiment aimed to evaluate characteristics related to forage yield, and the second experiment aimed to measure seed characteristics, such as dormancy levels.

Seeds from the cultivar ALPHA 94087 (A94087) were exposed to a Cobalt-60 source of gamma rays at doses of $0,10,50,100$, and $200 \mathrm{~Gy}$ at $0.25 \mathrm{~Gy} / \mathrm{min}$. For convenience, 
populations were named 0GYM4 (control), 10GYM4, 50GYM4, 100GYM4, and 200GYM4 according to the treatment.

First mutant generation $\left(M_{1}\right)$ seeds were sown separately in the winter of 2005 to obtain the $\mathrm{M}_{2}$ seeds. After harvesting, a germination test was conducted to test seed dormancy according to ISTA (2004). The seeds that germinated promptly (low levels of dormancy) were transplanted and harvested in bulk, forming the $\mathrm{M}_{3}$ generation. These plants were advanced to $M_{4}$ in a greenhouse in the winter of 2007 without further selection. From the $M_{4}$ generation onward, the only breeding criterion used was the absence of dormancy.

\section{First experiment}

The experiment was conducted in randomized blocks with 3 replications. The experimental units consisted of 2 rows that were $3 \mathrm{~m}$ long with row spacing of $0.20 \mathrm{~m}$ and 60 viable seeds per linear meter. In this experiment, a total of 3 forage cuts were applied, and the following characteristics were evaluated: i) plant height: measured before each cut, computed by the canopy length in centimeters from the soil surface to the youngest leaf (first and second cuts) or flag leaf (third cut); ii) dry matter yield (DMY): the green matter harvested above $8 \mathrm{~cm}$ was weighed, a subsample of ca. $300 \mathrm{~g}$ was extracted to estimate its dry matter proportion, the subsample was oven dried at $60^{\circ} \mathrm{C}$ for $72 \mathrm{~h}$ and weighed, and the DMY was expressed in $\mathrm{kg} / \mathrm{ha}$; iii) number of surviving tillers (NST) per $\mathrm{m}^{2}$ : measured a week after each cut by counting the number of culms in $0.5 \mathrm{~m}$ with extrapolation to $\mathrm{m}^{2}$; and iv) seedling stand: determined by the percentage of seedlings emerged in $0.5 \mathrm{~m}$ for each line, 28 days after sowing. The fertilizer and cultivation procedures were performed according to the culture requirements.

\section{Second experiment}

The experiment was conducted in a completely randomized design with 2 replications. The experimental units consisted of rows that were $3 \mathrm{~m}$ long and spaced $0.2 \mathrm{~m}$ with 60 seeds per linear meter. Seed yield was measured by the individual threshing of each line and was expressed in $\mathrm{kg} / \mathrm{ha}$.

To examine the variation in dormancy level, a germination test was performed 30 days after harvesting; this test evaluated the percentage of plants that germinated at 10 days according to the seed testing procedures for the genus Avena L. (ISTA, 2004). Genotypes forming seedlings within this period were considered to be without dormancy. The experiment was conducted in a randomized block design with 4 replications per treatment. After 10 days, the number of normal seedlings produced was counted.

\section{Statistical analyses}

Analyses of variance were performed for the traits seedling stand, seed yield, and dormancy considering the randomized blocks and completely randomized designs. Because seedling stand influences the dependent variables plant height, NST, DMY, and seed yield, analysis of covariance was conducted according to Steel and Torrie (1980) to remove the covariate effect before testing the treatment effects. The statistical model was given by: 


$$
\mathrm{y}_{\mathrm{ij}}=\mu+\alpha_{\mathrm{i}}+\mathrm{b}_{\mathrm{j}}+\beta\left(\mathrm{x}_{\mathrm{ij}}-\overline{\mathrm{x}}\right)+\varepsilon_{\mathrm{ij}}
$$

(Equation 1)

where $y_{\mathrm{ij}}$ is the response or dependent variable, $\mu$ is the overall mean value of the response variable, $\alpha_{\mathrm{i}}$ and $b_{\mathrm{j}}$ are effects of the ith treatment and jth block, $x_{\mathrm{ij}}$ is the covariate (seedling stand) on which $y_{\mathrm{ij}}$ has a linear regression with the regression coefficient $\beta, \bar{x}$ is the mean value of the covariate, and $\varepsilon_{\mathrm{ij}}$ is the random error. The adjusted means were used in the subsequent analyses.

Analysis of variance for the split-plot design was performed considering treatment (populations), cut, and blocks as fixed. The statistical model was given by:

$$
\mathrm{y}_{\mathrm{ijk}}=\mu+\alpha_{\mathrm{i}}+\mathrm{b}_{\mathrm{j}}+\varepsilon_{\mathrm{a}}+\gamma_{\mathrm{k}}+(\alpha \gamma)_{\mathrm{ik}}+\varepsilon_{\mathrm{b}}
$$

(Equation 2)

where $y_{\mathrm{ijk}}$ is the response; $\mu$ is the overall mean; $\alpha_{\mathrm{i}}$ and $\gamma_{\mathrm{k}}$ are the ith whole-plot (population) and kth subplot (cut) effects, respectively; $\alpha \gamma_{\text {ik }}$ is the ith whole-plot $\mathrm{x}$ kth subplot interaction effect; $b_{\mathrm{j}}$ is the jth block effect; and $\varepsilon_{\mathrm{a}}$ and $\varepsilon_{\mathrm{b}}$ are the whole-plot and subplot random errors, respectively.

Because dosage is a quantitative variable, the interaction effects of populations with seedling stand, DMY per cut, NST, plant height, seed yield, and dormancy were tested by regression analysis, verifying the fitting of distinct polynomial orders for the major traits as a function of different gamma-ray treatments. Pearson's correlation coefficients within each cut were estimated as a measure of the degree of linear dependence among the traits plant height, NST, and DMY. All of the analyses were performed using the Genes software (Cruz, 2013).

\section{RESULTS AND DISCUSSION}

The effects of populations, cut, and populations $\mathrm{x}$ cut interaction were significant ( $\mathrm{P}$ $\leq 0.05$ ) for all characteristics evaluated, indicating the presence of genetic variability among the populations tested. The coefficients of variation for the tested variables were low, ranging from 5 to $10 \%$ for plant height and NST, allowing for a higher reliability of the results obtained (Table 1).

Table 1. Summary of the analysis of variance for the split-plot model showing the sources of variation according to block, population, and cut for the following characteristics: plant height (PH), number of surviving tillers (NST), and dry matter yield (DMY).

\begin{tabular}{lcccc}
\hline Source of variation & d.f. & \multicolumn{3}{c}{ Mean squares } \\
\cline { 3 - 5 } & & $\mathrm{PH}^{\mathrm{a}}$ & $\mathrm{NST}^{\mathrm{b}}$ & DMY $^{\mathrm{c}}$ \\
\hline Block & 2 & 1.38 & 45004.69 & 563.89 \\
Population (P) & 4 & $16.78^{*}$ & $213761.56^{*}$ & $581549.54^{*}$ \\
Error A & 8 & 1.38 & 7615.38 & 5188.43 \\
Cut (C) & 2 & $160.03^{*}$ & $21630402.50^{*}$ & $38064386.75^{*}$ \\
P x C interaction & 8 & $3.02^{*}$ & $43231.42^{*}$ & $233061.77^{*}$ \\
Error B & 20 & 0.63 & 6420.09 & 4762.73 \\
Total & 44 & 37.84 & 1707.77 & 1288.17 \\
Mean & & 5.19 & 9.80 & 9.13 \\
Coefficient of variation & &
\end{tabular}

a PH in $\mathrm{cm}$; ${ }^{\mathrm{b} S T}$ per $\mathrm{m}^{2}$; and ${ }^{\mathrm{c}} \mathrm{DMY}$ in $\mathrm{kg} / \mathrm{ha} .{ }^{*}$ Significant at the $5 \%$ level by the $\mathrm{F}$ test. d.f. $=$ degrees of freedom. 
The significant population $\mathrm{x}$ cut interaction effect highlights the need for recommendations based on more than 1 harvest. Thus, regression analysis was performed to verify the variations in plant height, NST, and DMY for the populations at the different cuts.

The seedling stand showed a quadratic trend for the different levels of mutagenic treatment (Figure 1). The 100GYM4 mutant population expressed the highest value (250 plants $\left./ \mathrm{m}^{2}\right)$, followed by populations 10GYM4 (227 plants $\left./ \mathrm{m}^{2}\right)$ and 50GYM4 (217 plants $\left./ \mathrm{m}^{2}\right)$, representing 83,76 , and $72 \%$ establishment, respectively. All of the mutagenic treatments, with the exception of the highest dose, yielded higher values than the control (0GYM4), which showed 170 plants $/ \mathrm{m}^{2}$ (56\% establishment), indicating that an increase in seedling establishment was achieved by irradiation.

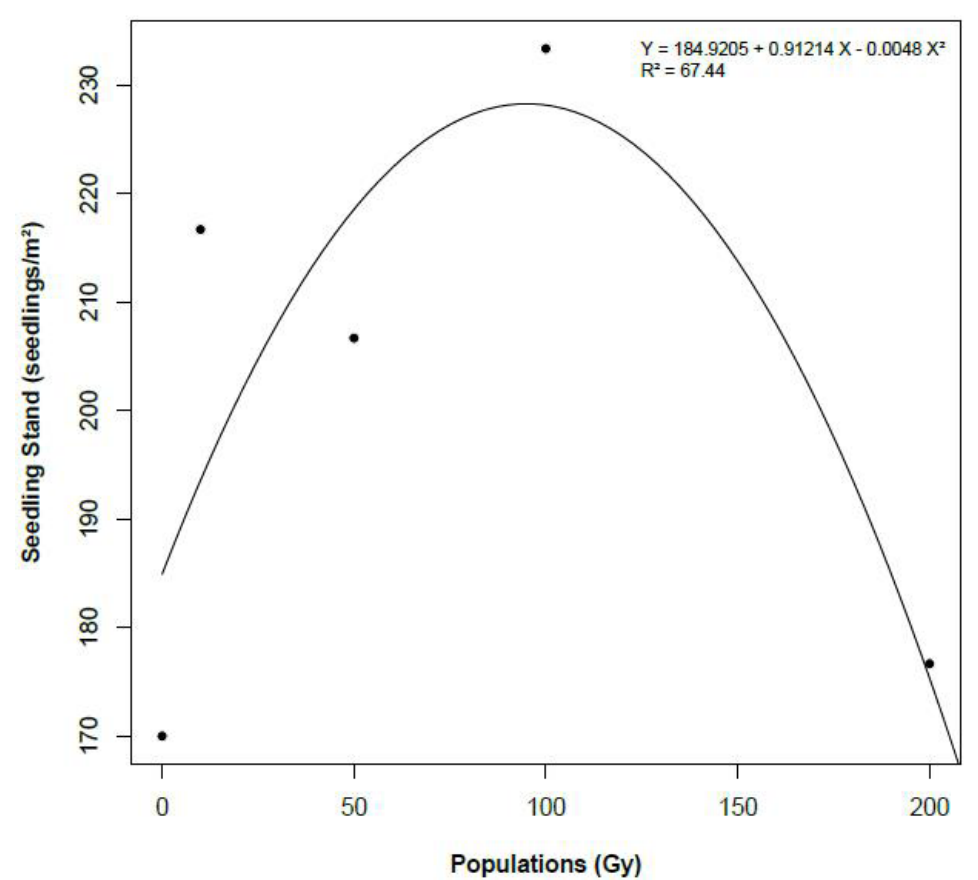

Figure 1. Regression fitted for seedling stand (seedlings $/ \mathrm{m}^{2}$ ) in mutant black oat populations that were obtained from 5 different doses of gamma irradiation.

Successful seedling establishment is directly related to seed vigor, a characteristic that is expressed by the rapidity of germination, seedling emergence, and establishment in the field (Willenborg et al., 2005). According to Rajjou et al. (2012), germination is considered to be the most critical phase in plant life and can influence both growth and yield, especially during the initial stages. Our results suggest that the 100-Gy treatment can be applied without loss of seed vigor.

\section{First experiment}

The regression analysis for total DMY as a function of the different mutagen doses showed a quadratic trend in all 3 cuts (Figure 2A), although the third cut presented a non- 
significant response for all of the tested polynomial orders. The first and second cuts showed negative and positive quadratic trends with determination coefficients $\left(\mathrm{R}^{2}\right)$ of 59 and $76 \%$, respectively.

A

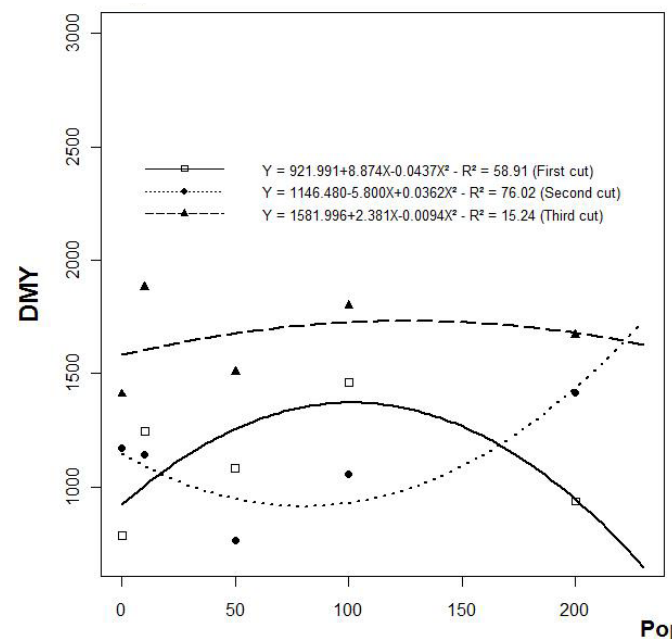

B

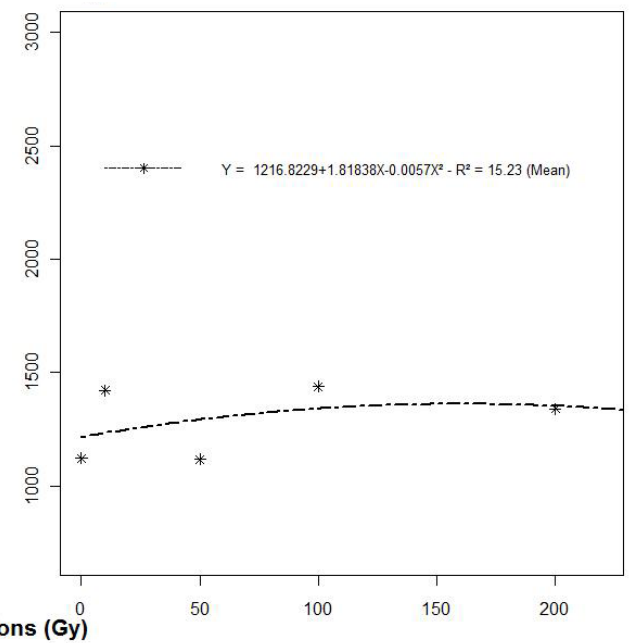

Figure 2. Regressions fitted for 3 cuts (A) and mean value of the cuts (B) for the characteristic dry matter yield (DMY, $\mathrm{kg} / \mathrm{ha}$ ) in mutant black oat populations that were obtained from 5 different doses of gamma irradiation.

The 200GYM4 population, which had reduced DMY in the first cut, showed higher yields for the second and third cuts. On the other hand, 50GYM4 and 100GYM4 showed the opposite behavior, i.e., reduced DMY in the second cut (Figure 2A). These results suggest that higher mutagen doses increased the dry mass production. The positive relationship between the dose of the gamma ray mutagen $\left[{ }^{60} \mathrm{Co}\right]$ and total DMY suggests the formation of new alleles (mutant genotypes) that favor an increase in DMY.

Considering the mean value of the 3 cuts (Figure 2B), the 10GYM4 and 100GYM4 mutant populations yielded the highest DMY values of $1422 \mathrm{~kg} / \mathrm{ha}$ and $1438 \mathrm{~kg} / \mathrm{ha}$, respectively. The 50GYM4 population yielded the lowest DMY $(1117 \mathrm{~kg} / \mathrm{ha})$, suggesting that this dose did not increase the frequency of favorable alleles, although some degree of variability could be observed within this population.

Black oat populations that express increased dry matter in successive cuts are usually composed by very early-heading genotypes, while those showing reduced yields in later cuts have a predominance of late-maturing genotypes (Cecato et al., 2008). In addition, a reasonable balance between the DMY of the different cuts obtained throughout the growth cycle should translate into a better dry matter distribution, which is a very important trait in forage crops. Considering this performance, the 100GYM4 population could be close to the ideotype.

Plant height and number of tillers are the most important characteristics related to dry matter production in forage species. According to Boe and Beck (2008), despite there are other characteristics related to forage yield, tiller number is probably the most important characteristic related to the DMY. However, for the first and third cuts, the plant height contributed more 
than NST to the yield of mutant populations, as shown by the positive and significant correlations (0.714 and 0.793, respectively) between DMY and plant height (Table 2).

\begin{tabular}{|c|c|c|c|c|c|c|c|c|c|}
\hline \multirow[t]{2}{*}{ Traits $^{\mathrm{a}}$} & \multicolumn{3}{|c|}{ First cut } & \multicolumn{3}{|c|}{ Second cut } & \multicolumn{3}{|c|}{ Third cut } \\
\hline & DMY & NST & $\mathrm{PH}$ & DMY & NST & $\mathrm{PH}$ & DMY & NST & $\mathrm{PH}$ \\
\hline DMY & 1 & 0.148 & $0.714 * *$ & 1 & $0.673^{*}$ & 0.579 & 1 & $0.642 *$ & $0.793^{* *}$ \\
\hline NT & & 1 & 0.387 & & 1 & 0.525 & & 1 & $0.685^{*}$ \\
\hline PH & & & 1 & & & 1 & & & 1 \\
\hline Mean & 1100.23 & 1003 & 34 & 1110.5 & 1026 & 40 & 1653.8 & 1065 & 49 \\
\hline
\end{tabular}

${ }^{\text {a }} \mathrm{PH}$ in $\mathrm{cm}$; NST per $\mathrm{m}^{2}$; and DMY in $\mathrm{kg} / \mathrm{ha} .{ }^{*},{ }^{* *}$ Significant at the 5 and $1 \%$ level, respectively, by the $\mathrm{F}$ test.

In some forage species, the selection of plants with lower stature can be promising because of the better protection of meristematic tissues. Also, short plants are more tolerant to grazing intensity because they have an escaping mechanism that protects a large number of residual leaves and base gems (Briske, 1996).

The NST in the second and third cuts had a positive and significant correlation $(0.673$ and 0.642 , respectively) with DMY (Table 2). This shows that grass genotypes present a differential response to producing/maintaining tillers after the first cut (Assuero and Tognetti, 2010). This suggests that a large number of vegetative buds remained active and ready to react to ambient stimuli after each cut, thus producing new tillers that contributed directly to DMY. Similar results were observed in switchgrass (Panicum virgatum L.), in which a 2-cut management increased tiller density and, consequently, forage yield (Fike et al., 2006). Therefore, this is evidence that an increase in DMY can be achieved by selecting genotypes with higher tillering potential.

\section{Second experiment}

The regression analysis for seed yield and dormancy level as a function of the different mutagen doses showed positive and negative quadratic trends with determination coefficients $\left(\mathrm{R}^{2}\right)$ of 26 and $18 \%$, respectively (Figure 3 ).

The 10GYM4 population showed the highest seed yield, $1242 \mathrm{~kg} / \mathrm{ha}$, which was $78 \%$ greater than the control treatment (0GYM4). The remaining populations had similar performances, with a mean yield of $686 \mathrm{~kg} / \mathrm{ha}$ (Figure 3). This result indicates that gamma irradiation seems not to increase seed yield, with the exception of the 10-Gy treatment. One important aspect of black oat use in the state of Rio Grande do Sul is related to the size of the cultivated area and the quality of the seed produced. Seed yields rarely exceed $500 \mathrm{~kg} /$ ha because of insufficient quality in terms of caryopsis size, germination, and vigor values (Debiasi et al., 2007).

The high disuniformity expressed by black oats for forage and seed yield associated with the presence of seed dormancy was responsible for the strong rejection of the use of this crop in agricultural systems because it determines the formation of dormant seed banks in the soil. This leads to the spontaneous growth of this species in fields that are cultivated with other winter crops. 


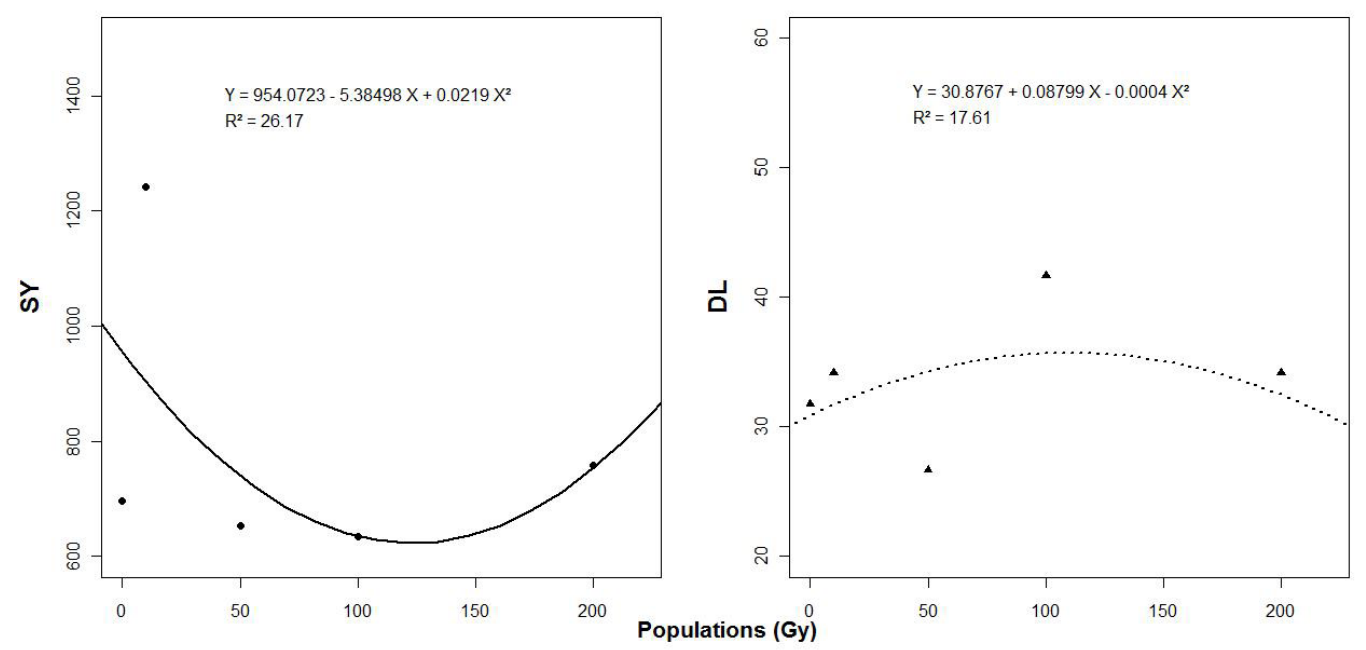

Figure 3. Regressions fitted for the characteristics seed yield (SY, kg/ha) and dormancy level (DL, \%) in mutant black oat populations that were obtained from 5 different doses of gamma irradiation.

The 100GYM4 population had the lowest dormancy level of $42 \%$ of germinated seeds. This result indicates that the 100-Gy treatment effectively generated variability in dormancy, a quantitative trait that is strongly affected by the environment in which the seeds develop (Benech-Arnold et al., 2000; Leubner-Metzger, 2003; Baskin and Baskin, 2004). A higher mutagen dose may influence metabolic pathways that are associated with physiological seed qualities, resulting in black oat populations with lower dormancy levels.

Considering that plant populations in this experiment developed from fourth-generation seeds that were selected for low dormancy levels, the percentage of seedlings was low (34\%). We observed even lower germination values, not higher than 26\% (10 Gy) and 10\% (100 Gy), in the $\mathrm{M}_{2}$ generation (data not shown). Therefore, the selection process for low dormancy level seems to be effective. Thus, the procedure of testing the germination percentage soon after seed harvest can aid breeders in the search for genetic gains for dormancy-associated traits in segregating black oat populations.

Induced mutations enabled the formation of novel gene structures due to genotypic frequency changes and/or chromosome alterations (Sahasrabudhe et al., 1991; Micke and Donini, 1993). However, these changes occur randomly along the DNA molecule, producing modifications either in a small number of genes with large effects on genotypes or in a large number of genes with small effects on genotypes (Gregory, 1969). These random mutations along the DNA molecule explain the changes observed in plant traits when plants are subjected to different doses of gamma irradiation, resulting in differences in the mean and variance values of the experimental population.

\section{CONCLUSIONS}

The use of gamma ray mutagens is a technique that induces variability in black oat and can be used to breed genotypes with high DMY and seed yield and low seed dormancy 
levels. Tiller number and plant height are important selection traits to increase DMY. Gamma irradiation seems not to increase seed yield in black oats, but it is effective for other characteristics. A germination test that is performed soon after harvesting, followed by seedling selection, is an efficient means to achieve genetic gains for low dormancy levels in black oat seeds. Therefore, selection in advanced generations can increase the probability of identifying superior genotypes.

\section{REFERENCES}

Ahloowalia B and Maluszynski M (2001). Induced mutations-a new paradigm in plant breeding. Euphytica 118: 167-173. Assuero SG and Tognetti JA (2010). Tillering regulation by endogenous and environmental factors and its agricultural management. Am. J. Plant Sci. Biotechnol. 4: 35-48.

Baskin JM and Baskin CC (2004). A classification system for seed dormancy. Seed Sci. Res. 14: 1-16.

Benech-Arnold RL, Sánchez RA, Forcella F, Kruk BC, et al. (2000). Environmental control of dormancy in weed seed banks in soil. Field Crops Res. 67: 105-122.

Boe A and Beck DL (2008). Yield components of biomass in switchgrass. Crop Sci. 48: 1306-1311.

Briske D (1996). Strategies of Plant Survival in Grazed Systems: A Functional Interpretation. In: The Ecology and Management of Grazing Systems (Hodgson J and Illius AW, eds.). CAB International, Wallingford, 37-67.

Cecato U, Sarti LL, Sakaguti ES, Damasceno JC, et al. (2008). Oat (Avena spp) cultivars and lines evaluation. Acta Sci. Anim. Sci. 20: 347-354.

CONAB (2013). Acompanhamento de Safra Brasileira: Grãos. Safra 2012/2013 - Décimo Levantamento, Julho/2013. CONAB. Available at [http://www.conab.gov.br/OlalaCMS/uploads/arquivos/13_07_09_09_04_53_boletim_ graos_junho_2013.pdf]. Accessed August 20, 2013.

Cruz CD (2013). GENES - a software package for analysis in experimental statistics and quantitative genetics. Acta Sci. Agron. 35: 271-276.

Debiasi H, Martins JD and Missio EL (2007). Grain yield and yield components of black oat (Avena strigosa Schreb.) as affected by seeding rate and velocity. Cienc. Rural 37: 649-655.

Ertekin M (2012). Genetic Diversity of Seed Orchard Crops. In: The Molecular Basis of Plant Genetic Diversity (Caliskan M, ed.). InTech, Manhattan.

Federizzi LC and Mundstock CM (2004). Fodder Oats: An Overview for South America. In: Fodder Oats: A World Overview (Suttie JM and Reynolds SG, eds.). FAO, Rome, 37-51.

Fike JH, Parrish DJ, Wolf DD, Balasko JA, et al. (2006). Switchgrass production for the upper southeastern USA: Influence of cultivar and cutting frequency on biomass yields. Biomass Bioenergy 30: 207-213.

Gregory WC (1969). Mutation Breeding. North Carolina State University, Raleigh.

ISTA (2004). International Rules for Seed Testing. International Seed Testing Association, Zurich.

Jain SM (2010). Mutagenesis in crop improvement under the climate change. Rom. Biotechnol. Lett. 15: 88-106.

Leubner-Metzger G (2003). Functions and regulation of $\beta$-1,3-glucanases during seed germination, dormancy release and after-ripening. Seed Sci. Res. 13: 17-34.

Micke A and Donini B (1993). Induced Mutations. In: Plant Breeding. Springer, New York, 52-62.

Rajjou L, Duval M, Gallardo K, Catusse J, et al. (2012). Seed germination and vigor. Annu. Rev. Plant Biol. 63: $507-533$.

Sahasrabudhe SR, Luo X and Humayun MZ (1991). Specificity of base substitutions induced by the acridine mutagen ICR-191: mispairing by guanine N7 adducts as a mutagenic mechanism. Genetics 129: 981-989.

Steel RG and Torrie JH (1980). Principles and Procedures of Statistics, A Biometrical Approach. 2nd edn. McGraw-Hill Kogakusha, Ltd., Tokyo.

Willenborg CJ, Wildeman JC, Miller AK, Rossnagel BG, et al. (2005). Oat germination characteristics differ among genotypes, seed sizes, and osmotic potentials. Crop Sci. 45: 2023-2029. 